\title{
大腿骨頚部骨折術後に大腿骨骨幹部骨折を来たした症例
}

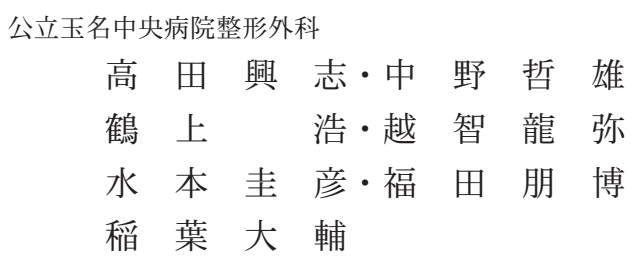

\section{Four Cases Caused Femoral Shaft Fracture after Operation of Femoral Neck Fracture}

\author{
Koji Takada, Tetsuo Nakano, Hiroshi Tsurukami, \\ Ryuya Ochi, Yoshihiko Mizumoto, Tomohiro Fukuda, \\ and Daisuke Inaba \\ Department of Orthopedic Surgery, \\ Tamana Central Hospital, Tamana, Kumamoto, Japan
}

We report four cases of femoral shaft fracture after operative treatment for femoral neck fracture. All cases were women aged 68 to 91 years. They were studied from January 1999 to June 2001. Three femoral shaft fractures occurred three months after operation for femoral neck fracture and were treated using the long gamma nail. One femoral shaft fracture occurred four months after operation and was treated using the intramedullary nail. Two cases were treated using the gamma nail without distal locking screw for the femoral neck fracture, one using the gamma nail with distal locking screw, and the remaining one using the compression hip screw and canulated cancellous hip screw.

In all cases, postoperative femur shaft fracture occurred in an early stage. Treatment for this fracture needs to be selected in consideration of union of the femur neck fracture. The long gamma nail and intramedullary nail were found to be useful for secondary femoral shaft fracture.

Key words : femoral shaft fracture (大腿骨骨幹部骨折), long- $\gamma$-nail（ロングガンマネイル), intramedullary nail（髄内釷）

\section{は じめに}

大腿骨澒部骨折に対する手術療法は, 多くの症例に おいて安定した成績が得られている。しかし, cut out や過度の sliding などの術後合併症の報告も見ら れる。中でも術後に発生する大腿骨骨幹部骨折は Gamma nail typeに多く, 問題となっている. 今回, 我々が経験した大腿骨頝部骨折術後に同側の大腿骨骨 幹部骨折を発生した 4 例について, 受傷時期, 一次骨
折の手術法, 二次骨折の治療法など文献的考察を加え 報告する.

$$
\text { 症例 }
$$

症例は 1999 年 1 月から 2001 年 6 月の期間中, 大腿 骨頝部骨折術後に同側の大腿骨骨幹部骨折を受傷した 4 例である．年齢 68～91 歳で全例女性であった．一 次骨折型は大腿骨転子部骨折 2 例, 大腿骨転子下骨折 1 例，大腿骨頝部内側骨折 1 例であった。 一次骨折の 
治療は，転子部および転子下骨折は Gamma nail type で, 頝部内側骨折に対しては, Ti-CHS, C-CHS を用いて骨接合術を行われていた.

二次骨折の受傷機転は全例転倒であった，二次骨折 受傷までの期間は, 大腿骨頚部骨折の術後から 2 例が 1 カ月で, 残り 2 例が 3 カ月と 4 力月であった.

\section{症 例 供 覧}

症例 1（図 1a， b)

91 歳，女性，右大腿骨転子部骨折に対するガンマ ネイル（横止めスクリューなし）の術後 3 カ月で転倒 した．ネイル先端部より骨幹部にかけて骨折線が見ら れた. long-Gamma-nail にて骨接合術施行した。 術 後 1 カ月で介助平行棒内歩行が可能となった.

症例 2（図 2a， b)

81 歳，女性，右大腿骨転子部骨折に対する Gamma-nail type（マルチフィックス，横止めなし） による骨接合術施行後 1 カ月で転倒して受傷した. ネ イル先端より骨幹部にかけて骨折線を認めたｌongGamma-nail 及びドールマイルズケーブルを用いて 骨接合術を施行した，術後 3 カ月で骨癒合したが，痴 呆症状が悪化し, 車椅子となった.

症例 3 (図 3a, b)

68 歳, 女性，右大腿骨転子下骨折に対し Gammanail（横止めスクリュー使用）及びドールマイルズケー ブルにて骨接合術を施行した，術後 1 カ月で再転倒し 受傷した。骨折線は横止めスクリューの穴より骨幹部 にかけて認めた．long-Gamma-nail にて骨接合術施 行した. 術後, 受傷前と同レベルである車椅子となつ た.

症例 4（図 4a，b)

80 歳, 女性, 左大腿骨頚部内側骨折（garden stage 1) に対し Ti-CHS，C-CHS にて骨接合術を施 行した。術後約 4 カ月にて転倒し受傷した。髄内釷， ドールマイルズケーブル及び頝部に C-CHS を用い骨 接合術施行した。骨癒合良好で，1本杖歩行となった．

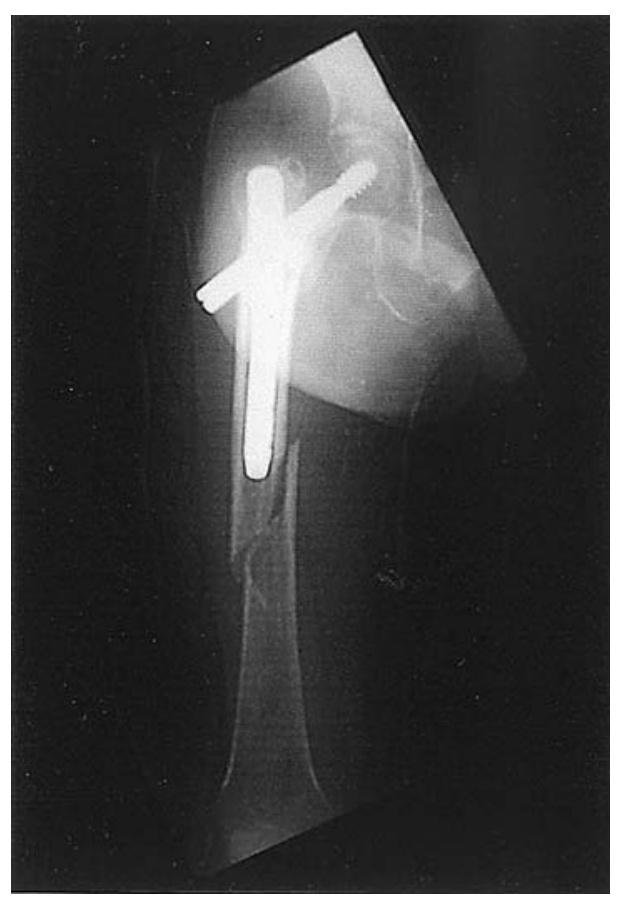

a. 受傷時

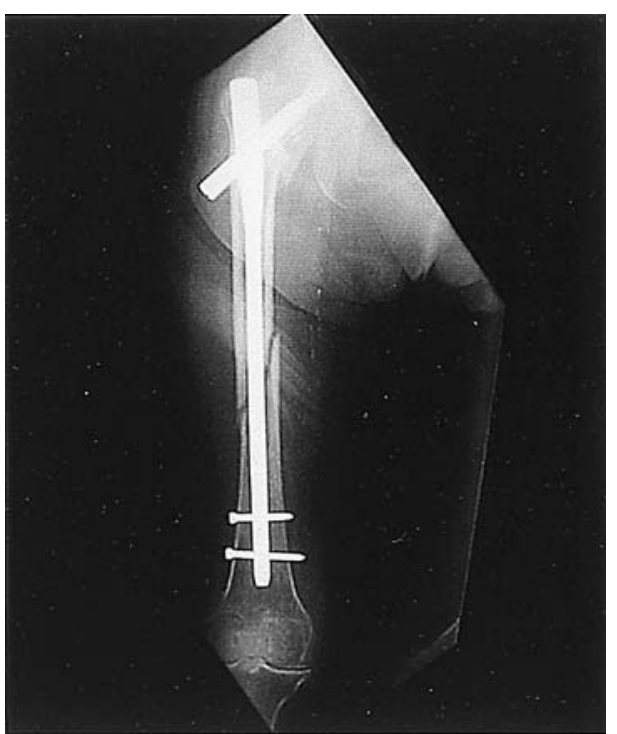

b. 術後

図 1 症例 1 


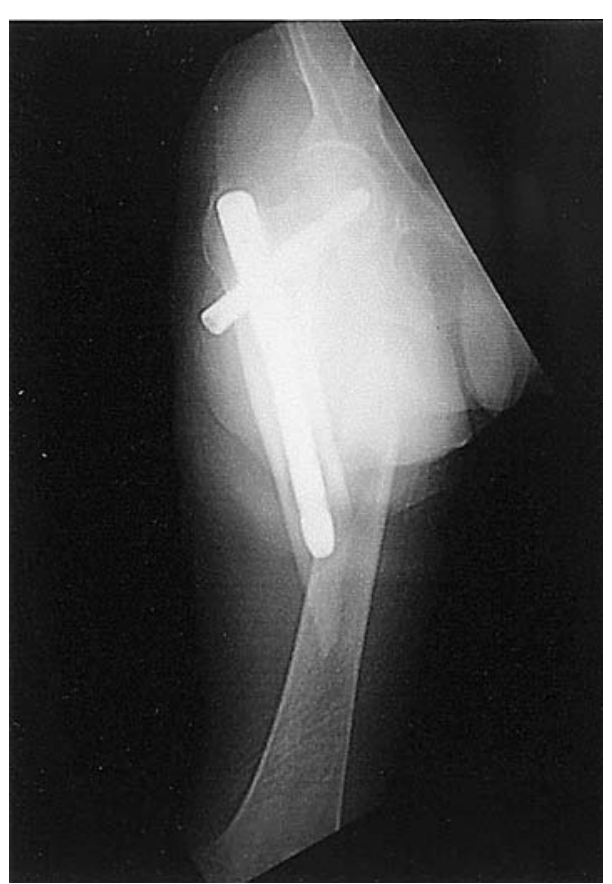

a. 受傷時

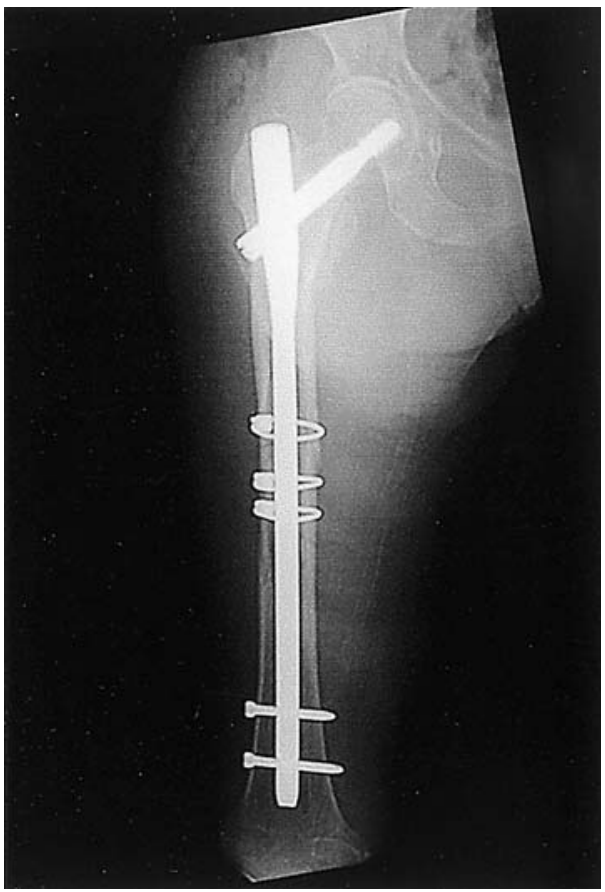

b. 術後

図 2 症例 2
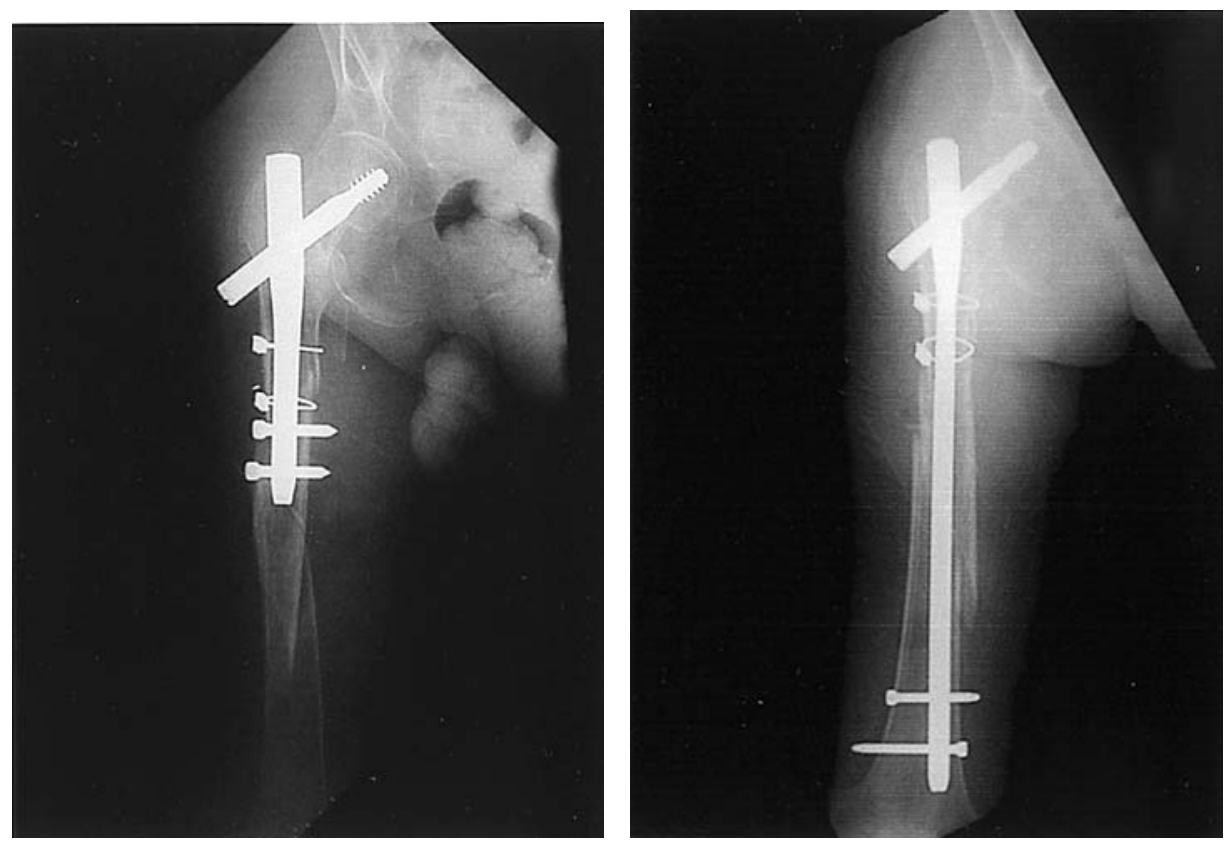

a. 受傷時

b. 術後

図 3 症例 3 


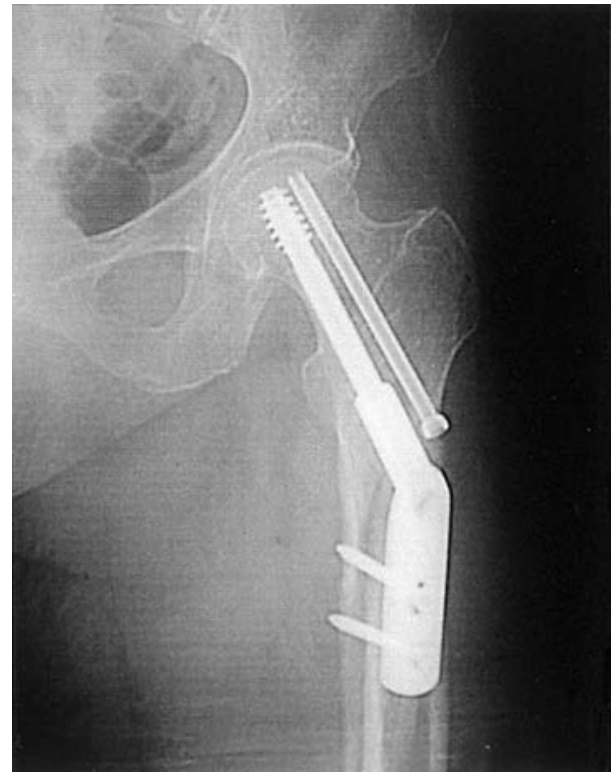

a. 受傷時

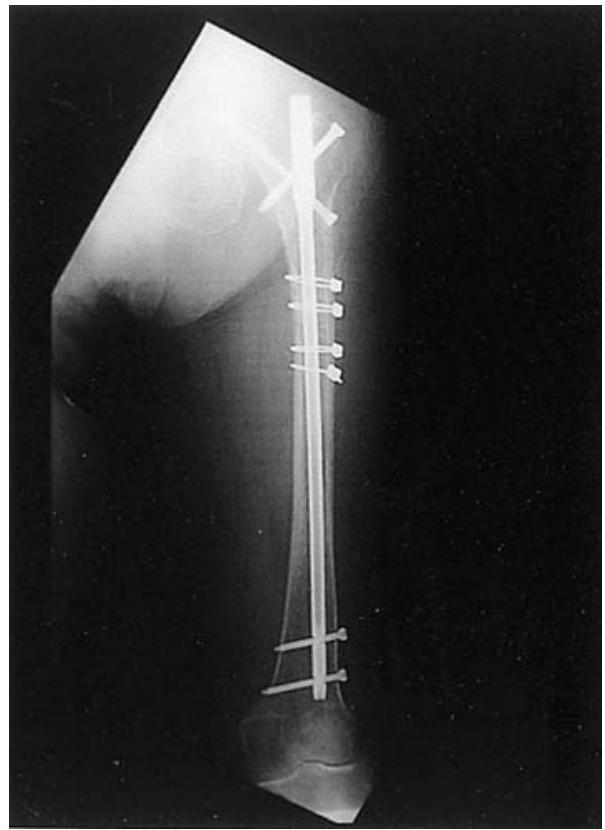

b. 術後

図 4 症例 4

\section{考察}

大腿骨頚部骨折の骨接合術後二次的大腿骨骨幹部骨 折は Gamma nail type に多くの報告があり，本術式 の重要な問題とされている.

Gamma nail type 術後における二次的大腿骨骨幹 部骨折の発生頻度は, Bridle ら ${ }^{1)}$ は欧米では 2 11\%, 正田ら ${ }^{6)}$ は $3 \%$ と報告しており，当院では 1998 年 12 月から 2001 年 6 月までで 64 例中 3 例で, $4.7 \%$ であつ た（表 1)。それに対して，当院における CHS 術後の 発生頻度は同期間中 121 例中 1 例であった。 CHS 術 後の二次的大腿骨骨幹部骨折の報告は，我々が調べた 範囲では無かつた，大腿骨頚部骨折術後の二次的大腿 骨骨幹部骨折は，CHS 術後より Gamma nail type 術後に多いことが示唆された.

表 2 に本症例を含め，これまで国内の文献 ${ }^{2-4) 6-9)} に$ おいて提示された Gamma nail type 施行後，大腿骨 骨幹部骨折を来たした症例を挙げた。平均年齢 75.0 歳で，平均受傷期間は 19 週で転倒した 1 例を除き平 均 22.8 日であった。岡田らが報告した ${ }^{5}$ 術後大腿骨 骨幹部骨折を起こした 5 例の平均受傷期間は 19 日で
表 1 Gamma nail type 術後における二次的大腿骨 骨幹部骨折の発生頻度

\begin{tabular}{lr}
\hline \hline Bridle 5 & $2 \sim 11 \%$ \\
正田ら & $3 \%$ \\
当院 & $4.7 \%$ \\
\hline
\end{tabular}

あった.この事より, 多くの症例においては, 二次的 大腿骨骨幹部骨折の発生時期は，大腿骨頚部骨折の骨 癒合が見られる以前である事が推測された。

受傷機転は転倒の他，体位変換，起立時など軽微な 外力で発生している症例もあり, Gamma nail type の術後リハビリテーションや介助には十分注意する必 要がある.

遠位横止めに関しては，その有無にかかわらず発生 していた. 10 例中横止め有り 6 例，横止めなし 4 例 であった.

二次的大腿骨骨幹部骨折の治療法に関しては，䯣内 釷, long Gamma nail, plate 固定, wiring, 保存 的療法が考慮されている，我々は， lag screw 抜去後 の骨欠損, 一次骨折の骨癒合の状態, 術後のゴール設 定を考慮し，大腿骨頝部骨折部が骨癒合完成していな 
表 2 Gamma nail type 施行後大腿骨骨幹部骨折を来たした症例

\begin{tabular}{ccccccc}
\hline \hline 年齢 & 性別 & 受傷時期 & 受傷機転 & distal locking & 治療法 & 報告者 \\
\hline 92 & $\mathrm{~F}$ & 8 日 & 不明 & + & plate & 谷本ら \\
88 & $\mathrm{~F}$ & 16 日 & 転倒 & + & long- $\gamma$-nail + plate & 三好ら \\
70 & $\mathrm{~F}$ & 18 日 & 転倒 & - & distal locking + wire & 岡田ら \\
84 & $\mathrm{~F}$ & 28 日 & 体位変換 & + & IMHS long nail & 藤原ら \\
74 & $\mathrm{~F}$ & 1 力月 & 転倒 & + & long- $\gamma$-nail & 吉田ら \\
68 & $\mathrm{~F}$ & 1 力月 & 転倒 & + & long- $\gamma$-nail & 症例 3 \\
81 & $\mathrm{~F}$ & 1 力月 & 転倒 & - & long- $\gamma$-nail +wiring & 症例 2 \\
79 & $\mathrm{~F}$ & 42 日 & 起立時 & + & long- $\gamma$-nail & 山口ら \\
91 & $\mathrm{~F}$ & 3 力月 & 転倒 & - & long- $\gamma$-nail & 症例 1 \\
86 & $\mathrm{M}$ & 19 週 & 転倒 & - & 髄内釘 & 田上ら \\
\hline
\end{tabular}

表 3 当院での二次的大腿骨骨幹部骨折の治療方針

1. 受傷時期が早期で大腿骨䅡部骨折部が骨癒合完成していないと思われる症例

2. 大腿骨頚部の骨癒合が得られていると思われる症例

$\longrightarrow$ 髄内釘

3. 術前歩行可能で早期荷重を目指す症例には骨幹部骨折部に wiring を追加

いと思われるものに long-Gamma-nail，大腿骨頚部 の骨癒合が得られていると思われるものに䯣内釘を用 いる事にしている（表 3)。 また, 術前歩行可能で早 期荷重を目指す症例には骨幹部骨折部に wiring を追 加した．長期経過が追えた症例 $2 ， 4$ はいずれも骨癒 合が得られていた. 歩行能力の再獲得は, 症例 2 は痴 呆悪化のため十分なリハビリが行えず, 平行棒内の立 位までとなったが, 症例 4 は受傷前と同レベルまで改 善した.

大腿骨頚部骨折の術後二次的大腿骨骨幹部骨折に対 しては, long Gamma nail もしくは髄内釘を用いた 手術療法が有用であると考えられた.

\section{結語}

大腿骨頚部骨折術後に同側の大腿骨骨幹部骨折を受 傷した 4 例を治療した.

大腿骨頚部骨折術後の二次的大腿骨骨幹部骨折に対 し, long Gamma nail, 髄内釘を用いた手術療法は 有用であった.

\section{参 考 文 献}

1) Bridle, S.H. et al.: Fixation of intertrochanteric fracture of the femur: a randomized prospective comparison of the Gamma nail and the dynamic hip screw. J. Born Joint Surg., 73-B : 330-334, 1991.

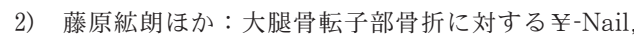
CHY-Nail の使用経験. 骨折, $19:$ 130-136, 1997.

3）金子正剛ほか：大腿骨転子部骨折に対するIntrameduallry Hip Screw の使用経験. 骨折, 19: 164-167, 1997.

4）三好信也ほか：Gamma nail 使用後の大腿骨二次的骨 折について. 骨折, $19: 142-147,1997$.

5）岡田純典ほか：Gamma nail による大腿骨転子部骨折 手術の合併症. 骨折, $19: 148-151,1997$.

6）正田悦郎ほか：大腿骨転子部および転子下骨折に対す る Gamma nail. MB, orthop., 13(5) : 51-60, 2000.

7）谷本 真ほか：大腿骨頚部外側骨折に対する $\gamma$ ネイル 法による治療経験。骨折, 19 : 124-129, 1997.

8）田上敦士ほか：ガンマネイル法による骨接合術後に 大腿骨骨折を合併した症例の検討. 整・災害，50(4)： 1067-1071, 2001.

9）吉田健治ほか：大腿骨転子部骨折に対する治療法一特 に Gamma nail 法を中心として一. MB, orthop., 14 (9) : 139-147, 2001. 